\title{
Diyaliz Tedavisi Gören Anne ve Bebeğinin Hemşirelik Yönetimi: Bir Olgu Sunumu
}

\section{Nursing Management of the Mother and Her Baby Undergoing Dialysis Treatment: A Case Report}

${ }^{1}$ Öznur TIRYAKİ, ${ }^{2}$ Nursan ÇINAR, ${ }^{3}$ İbrahim CANER

\author{
${ }^{1}$ Sakarya Üniversitesi Sağlık Bilimleri Enstitüsü Hemşirelik ABD, Sakarya, Türkiye \\ ${ }^{2}$ Sakarya Üniversitesi Sağlık Bilimleri Fakültesi, Cocuk Sağlığı ve Hastalıkları Hemșireliği ABD, Sakarya, Türkiye \\ ${ }^{3}$ Sakarya Üniversitesi Tıp Fakültesi, Sakarya Eğitim ve Araştırma Hastanesi Çocuk Sağlığı ve Hastalıkları AD. Neonatoloji Bilim Dalı, \\ Sakarya, Türkiye
}

\section{ÖZ}

Diyaliz programı uygulanan doğurgan çağdaki kadınlarda gebelik son derece nadirdir. Son yıllarda diyaliz yöntemlerindeki gelişmeler, hasta takibindeki iyileşmeler ve multidisipliner hasta yaklaşımları nedeniyle bu hasta grubunda da fertilizasyon olasılığ 1 ve gebelik sonrası canlı doğum oranları artmaktadır. Bu yazıda dört yıldır diyaliz tedavisi gören primipar annenin takipleri, diyaliz tedavisi ve bebeğinin ilk altı aylık büyüme süreci sunuldu.

Anahtar Kelimeler: Bebek, diyaliz, emzirme, gebelik, hemşirelik

\begin{abstract}
Pregnancy is extremely rare in women of fertile age who underwent dialysis program. In recent years, due to the developments in dialysis methods, improvements in patient follow-up and multidisciplinary patient approaches, the possibility of fertilization and live births after pregnancy have increased in this patient group. In this paper, follow-up of the primipar mother, who has been on dialysis for four years, dialysis treatment and the first six months of her baby's growth process were presented.
\end{abstract}

Keywords: Infant, dialysis, breastfeeding, pregnancy, nursing
Sorumlu Yazar / Corresponding Author:

Öznur Tiryaki

Doktora Öğrencisi; Sakarya Üniversitesi Sağlık Bilimleri Enstitüsü

Hemşirelik ABD, Sakarya, Türkiye.

Telephone: $02644445400 /+95058836246$

Fax: +902642759192

E-mail: oznuritiryaki@gmail.com
Yayın Bilgisi / Article Info:

Gönderi Tarihi/ Received: 09/06/2020

Kabul Tarihi/ Accepted: 06/08/2020

Online Yayın Tarihi/ Published: 30/09/2020

Atıf/ Cited: Tiryaki Ö ve ark. Diyaliz tedavisi gören anne ve bebeğinin hemşirelik yönetimi: Bir olgu sunumu. Online Türk Sağlık Bilimleri Dergisi 2020;5(3):548-552. doi: 10.26453/otjhs.749764

\section{Giriș}

Üreme çağındaki diyaliz hastalarında gebelik insidans1 \%1-7 arasında olup, bu oran ülkelere göre farklılık göstermektedir. ${ }^{1}$ Diyaliz alan gebelerde en sık görülen maternal komplikasyonlar; spontan düşük, küretaj, plasental abrupsiyon, anemi, enfeksiyon, erken membran rüptürü, polihidroamnios, erken doğum, kontrol edilemeyen hipertansiyon, preeklampsi-eklampsi, kanama ve anne ölümüdür. ${ }^{2,3}$ Fetal komplikasyonlar; intrauterin büyümeyi geriliği (IUGR), akut ya da konik fetal sıkıntı, prematüritelik, yenidoğanda solunum sıkıntısı, intrauterin ölüm ve yenidoğan ölümü şeklinde sıralanmaktadır.,
Literatür incelendiğinde doğumdan sonraki süreçte diyaliz tedavisi alan annelerin bebeklerinin bakım, beslenme ve takiplerinin nasıl yapılacağı ile ilgili çalışmalar yetersizdir. Bu doğrultuda sunduğumuz olgu çalışması ile diyaliz tedavisi gören primipar annenin takipleri, diyaliz tedavisi ve bebeğinin ilk altı aylık büyüme süreci literatür eşliğinde tartışılacaktır.

\section{OLGU SUNUMU}

Bebeğin ve annenin tıbbi verilerinin yayınlanabileceğine ilişkin olarak anneye ayrıntılı bilgi verildi ve anneden yazılı, imzalı izin belgesi alındı. Dört yıldır hemodiyaliz (HD) tedavisi (haftada 6 
defa günde 5 saat) uygulanan 40 yaşındaki hasta adet gecikmesi nedeniyle doktora başvurmuş. Serum beta -hCG değeri yüksek saptanan hastada ultrasonografi incelemesi ile 5 haftalık gebelik saptanmış. Anne, gebeliğinin 26. haftasında kadın doğum poliklinik kontrolüne geldiğinde yapılan doppler USG incelemesinde umbilikal arter kan akımında yer yer kayıp gözlenmesi ve gebelik hipertansiyonu olması nedeniyle hastaneye yatırıldı. Yatışı devam ederken 30 . gebelik haftasında polihidroamnios saptandi. Klinikte yatışının 57. gününde takip ve tedavisi devam ederken umbilikal arterde ters akım ve fetal bradikardi gelişmesi nedeniyle acil olarak sezaryene alındi.

Gebelik haftası 33 hafta 4 gün ile uyumlu, 1370 gram ağırlığındaki kız bebek, doğar doğmaz hemen ağladı. Bebeğin doğduğunda hemen ağladığı, vücut renginin pembe ancak kol ve bacaklarının mor olduğu, kolların ve bacakların öne doğru bükülü olduğu, spontan solunumunun olduğu ve kalp tepe atımının 125/dk olduğu görüldü. Hastanın Apgar skorlaması 1. dakikada 6 puan ve 5 . dakikada 7 puan olarak hesaplandı. Hastanın riskli yenidoğan olması, morluklarının olması ve Apgar skorunun düşük olması nedeniyle Yenidoğan Yoğun Bakım Ünitesi'ne (YYBÜ) transferi ve yatışı sağlandı. Hasta monitörize edilerek damar yolu açıldı ve $70 \mathrm{ml} / \mathrm{kg}$ 'dan \%10 Dekstroz infüzyonu (glikoz infüzyon hızı 4.86 mg// $\mathrm{kg} / \mathrm{dk}$ ) başlandı. Aldığı çıkardığı takibi, kan basıncı ölçümleri ve kan şekeri takipleri yapıldı. Hastanın vital bulguları stabil seyretti ve kan şekeri ölçümleri normal saptandi. Klinik takiplerinde bebeğin morarmalarının düzelmesi, satürasyonlarının iyi olması ve solunumunun rahat olması nedeniyle oksijen tedavisi kademeli azaltılarak kesildi. Hastanın ilk 24 saat içinde idrarını ve gaitasını yaptığ 1 gözlendi.

Bebeğin yattığı süre içerisinde tam kan sayımı, işitme tarama testi, Ekokardiyografi (EKO), Abdominopelvik ve Kraniyal USG testleri yapıldı. Aşı takvimi düzenlendi, taburculuk sonrası aile sağlığı merkezinde aşılarına devam etmesi önerildi. İlk 6 ayda aşı takvimine göre toplam 13 doz aşı uygulandı. Hastanede yattığı dönemde sağ kulak işitme testi anormal olan bebeğe taburcu olduktan bir hafta sonra kontrole geldiğinde tekrar işitme testi uygulandı ve normal olarak değerlendirildi. Kraniyal USG'de Evre I hemoraji tespit edilen bebek taburculuk sonrası Çocuk Nöroloji ve Beyin Cerrahi klinikleri tarafından poliklinik takiplerine alındı.

Anneye bebek bakımı ve beslenmesi hakkında eğitimler hem gebeliğinde hem doğumdan sonraki ikinci gününde yenidoğan hemşiresi ve emzirme danış- manı hemşiresi tarafından verildi. Bu eğitimler doğrultusunda, anneden elle süt sağması istendi. Doğumdan üç saat sonra bebeğini görmeye gelen babaya 30 dakika kanguru bakımı uyguland. Kanguru bakımı sonrası baba 'kendimi muhteşem hissediyorum' şeklinde duygularını ifade etti. Postnatal ikinci günde sekiz öğün üç ml enteral beslenme başlandı. Beslenme sonrası batın distansiyonu gelişen bebeğin rezidü kontrolünde beslenmeyi tolere edemediği gözlendi. Total parental nütriyon (TPN) ile beslenmeye devam edildi. Postnatal üçüncü günü bebeğini görmeye gelen anneye kanguru bakımı uyguland. Emme, arama refleksi aktif olan bebeğe anne memesinden emzirme denendi fakat başarılı emzirme gerçekleşmedi. Tekrar enjektörle üç $\mathrm{ml}$ beslenme denendi, rezidü kontrollerinde beslenmeyi tolere ettiği görüldü. Postnatal beşinci gün anneyi emmeye başladı, kademeli olarak oral beslenmesi artırılarak postnatal altıncı gün TPN sonlandırıldı ve tamamen oral beslenmeye geçildi. Günde sekiz öğün olarak planlanan beslenme programında anne sütünün yetersiz olması nedeniyle iki-üç ögün sadece anne sütü diğer öğünler ise formüla ile desteklendi. Beslenme takibi için yatışı devam eden bebeğin annesinin doğum sonu kullandığı ilaçları ve diyaliz solüsyonları emzirmeye engel olmayacak şekilde ilgili hekimler tarafından düzenlendi. Yatışının 15. gününde anne uyum odasına yerleştirildi. Annenin HD tedavisinde (haftada 3 gün, 4 saat) olduğu sürelerde bebek YYBÜ'sinde hemşirelerin gözetiminde idi. Aile entegre bakım yaklaşımı ile uyum odasında bebeğinin invaziv olmayan tüm bakımlarına (alt bakımı, banyo, cilt bakımı, kanguru bakımı vs) dahil oldu ve taburculuk için hazırlandı. Bebek postnatal ilk 21 gün içinde 310 gr kilo alımı kaydederek 1680 gr (\%3 -10 persentil) ağırlığında taburcu oldu. Bebeğin günde sekiz öğün olan beslenmesinin ortalama 5-6 öğünün de sadece anne sütü, diğer öğünlerde preterm formüla desteği alacak şekilde taburculuk sonrası evde beslenmesi devam etti. Anneyi emen bebek için anne sütü zenginleştiricisi önerilmedi. Taburculuk sonrası düzeltilmiş yaşa göre birinci, ikinci, üçüncü ve altıncı aylarda beslenme ve sağlık kontrolleri yapildı (Tablo 1).

Üçüncü ay kontrolünde gelişimsel kalça displazisi açısından değerlendirildi ve bir problem olmadığ 1 saptand1. Çocuk Nöroloji uzmanı tarafindan el ve ayaklarına evde uygulanabilecek koruyucu fizik tedavi egzersizleri önerildi. Kontrollerinde herhangi bir patoloji saptanmadi. Her doktor kontrolünde emzirme danışmanı hemşiresi tarafından bebeğin beslenmesi, boy ve kilo alımı sorgulandı ve değerlendi- 
rildi. Başarılı emzirme ve anne sütü alımının devam etmesi için anne desteklendi. Anne sütü ve tamamlayıcı ek besinlerle ilgili emzirme danışmanlığı desteği devam eden bebek altıncı ayında 6300 gram (25 p), nörolojik açıdan bir patolojisi olmadan sağlıkla büyümektedir

Anneye gebeliğinde iki defa kadavradan böbrek nakli için firsat çıkmış olup gebelik nedeniyle bu nakil firsatları değerlendirilememiştir. Ayrıca annenin gün içerisinde toplam $1500 \mathrm{ml}$ sıvı alması ve iki HD arasında en fazla 3500 gram ağırlık alabileceği doktoru tarafindan önerildi.

\section{TARTIŞMA VE SONUÇ}

Yoğun uygulanan diyaliz tedavisi, diyaliz hastaları arasında doğurganlığı ve gebelik sonuçlarını iyileştirmektedir. ${ }^{2,4}$ Chou ve ark. ${ }^{5}$ haftada 15-27 saat, Sulaiman ve ark. ${ }^{6}$ ise haftada 6 gün 4 saat olarak hastalarına yoğun HD seansları uygulamışlardır. Olgu sunumundaki bebeğimizin annesi de haftada 6 gün, günde 5 saat HD tedavisi alarak yapılan çalışmalarla benzer özellik göstermektedir. Yapılan çalışmalarla uyumlu şekilde, gebelikte HD seanslarının ve sıkl1ğının artırılması maternal ve fetal iyilik halini olumlu etkilediğini düşünmekteyiz.

Jesudason ve ark. ${ }^{7}$ diyaliz tedavisi gören 77 gebe ile yaptığı araştırmada, ortalama doğum haftasını 33,8, ortalama doğum ağırlığını ise 1750 gr olarak saptamışlardır. Olgumuzda prematürelik ve IUGR olması bu çalışmanın sonuçları ile benzer özellik göstermektedir. Bu nedenle, özellikle prematüre doğum beklentisi nedeniyle bebeğin YYBÜ'sine ihtiyacı öngörülmeli ve yenidoğan ekibi ile koordinasyon halinde sürecin yönetilmesi gerekmektedir.

Diyalize giren kadınlar bebeklerini isterlerse emzirebilirler. Aşırı yoğun ultrafiltrasyon ve bunun sonucu oluşacak dehidratasyon annenin süt üretimini engelleyebilir, bu sebeple diyalize giren, emziren annelerde aşırı yoğun ultrafiltrasyon kaçınılmalıdır. ${ }^{8}$ Emzirmeyi tercih eden kadınların ilaç kullanımında da kısıtlamalar vardır. Çünkü hamilelikte kullanılan bazı ilaçlar emzirme döneminde kullanılamaz. ${ }^{8}$ İlaçların birçoğu anne sütüne geçtiği için, emzirme döneminde asıl sorgulanması gereken ilacın anne sütüne geçen miktarının bebekte yan etkiye neden olup olmadığıdır. Emziren her anne ayrı değerlendirilmelidir. Göreceli bebek dozu \%10'un altında olan, kısa yarılanma ömürlü, proteine yüksek oranda bağlanan, oral emilimi ve yağda çözünürlüğü düşük ilaçlar tercih edilmelidir. ${ }^{9}$ Emzirme döneminde ilaç kullanımiyla ilgili risk değerlendirmesinde başvurulabilecek elektronik ve basılı kaynaklar bulunmaktadır.
Diyaliz tedavisi alan annelerin antenatal dönemde kullandığı ilaçlarının doğum sonrası süte geçip geçmediği sorgulanmalıdır. Bu sorgulama eksik yapılırsa bebeğin anne sütünden yararlanması beklenirken farkında olmadan bebeğe zarar verilebilir. Annenin diyaliz sürecinde ve sonrasında sürekli kullandığg ilaçları nefroloji uzmanı, yenidoğan uzmanı, eczacı, farmakoloji uzmanı ve emzirme danışmanı hemşiresi tarafından kapsamlı şekilde değerlendirilmelidir. Sağlık çalışanları emzirme döneminde ilaç seçimi yaparken güvenilir kaynaklardan yararlanmalıdır.

Balzer ve ark. ${ }^{10}$ tarafindan yapilan incelemede diyaliz tedavisi alan annenin sütünün analiz raporu bugüne kadar bilinen ilk ve tek çalışmadır. Balzer ve ark. ${ }^{10}$ çalışmada haftada üç kez HD tedavisi gören son dönem böbrek hastalığı olan bir anne, bebeğini doğum sonrası on hafta boyunca kısmen emzirmiştir. Anne sütü örnekleri doğum sonrası 10. gün ile 10 . hafta arasında çeşitli zamanlarda toplanmış ve bu sütler böbrek veya başka bir kronik hastalığı olmayan kontrol grubundaki altı annenin sütüyle karşılaştırılmıştır. Bu sütlerin protein, trigliserit, kolesterol ve immünoglobulin içeriklerinin kontrol grubu ile bezer özellikte olduğu ifade edilmiştir. Hemodiyaliz tedavisi alan annenin sütünün üre, kreatinin, ürik asit, sodyum ve klor değerlerinin kontrol grubuna göre daha yüksek; fosfat değerinin ise daha düşük olduğunu tespit etmişlerdir. Yüksek bulunan bu değerler HD sonrası azalmıştır. HD sonrası özellikle anne sütündeki üre değerinin normal seviyede olduğunu vurgulamışlardır. HD öncesi ve sonrası anne sütü içeriğindeki önemli farklılıklar nedeniyle emzirmenin tercihen HD tedavisinden sonra yapılmasını önerilmektedirler. ${ }^{10}$

HD tedavisi alan bir gebe şiddetli hipertansiyon atağ1 nedeniyle 29. gebelik haftasında iken acil sezeryana alınmış ve 780 gr ağırlığında preterm bir bebek dünyaya getirmiştir. Altmış gün sonra tam beslenen ve nazal oksijen almaya devam eden bebek 1700 gr ağırlığına ulaşmış ve taburculuğu yapılmıştır. $\mathrm{Bu}$ bebeğin ilk altı aylık izleminde ek bir problemin saptanmadığ 1 bildirilmektedir. ${ }^{3}$ Sulamiman ve ark. ${ }^{6}$ 2003-2010 yılları arasında HD uygulan dört gebenin bebeklerini incelemişlerdir (doğum haftaları 27-34 hafta arasında). Bebeklerden birinin üç yaşında sağlıklı olduğu, başka bir bebeğin sadece sağlık durumunun iyi olduğu, iki bebeğin ise son durumu hakkında veriye ulaşılamadığını bildirmişlerdir. Dinelli ve ark. ${ }^{11}$ yaptıkları vaka-kontrol çalışmasında böbrek nakli olan annelerin bebeklerinde (vaka) prematürelik ve IUGR oranının yüksek olduğu, ilk bir yaş takiplerinde büyüme süreçlerinin normal ilerlediğini, 
kontrol grubuna göre hastaneye yatış riskinin daha yüksek olduğunu vurgulamışlardır. Sgro ve ark. ${ }^{12}$ araştırmalarında böbrek yetmezliği olan annelerin çocuklarını (n:32) 3 ay ile 11 yıl arasındaki sürelerde takip edilmişlerdir. Takip edilen çocuklardan birinde diabetes mellitus, ikisinde astım, birinde orta derecede işitme kaybı, birinde öğrenme güçlüğü, birinde yaygın gelişimsel bozukluk olduğunu ifade etmişlerdir. ${ }^{12}$ Yapılan çalışmalar genelde yenidoğan dönemine ait sonuçlarla sınırlı kalmıştır. Çocukluk dönemine ait verilerin yetersizliği nedeniyle bu konuda daha geniş vaka serilerine, daha uzun süreli ve prospektif çalışmalara gereksinim vardır.

Diyaliz tedavisi alan gebelerin yoğun diyaliz progra$\mathrm{m} 1$ ile hem annenin hem bebeğin sağlığının korunduğunu ifade eden çalışmalarda çoğunlukla anne sağl1ğına vurgu yapılmıştır. Bebeklerin ise değerlendirmesi doğum ve doğum sonrası dönemine ait kısa atıf yapılan araştırmalarla sınırlı kalmıştır. Günümüzde kronik böbrek hastalıkları ve buna bağlı HD tedavisi alan hastaların sayısı artmaktadır. Diyaliz tedavisi alan anne bebeklerine YYBÜ'sindeki yaklaşımın nasıl olması gerektiği, daha sonra çocuk izleminde neler yapılacağına ait güncel bir rehber bulunmamaktadır. Bu olgu sunumunun pediatride çalışan ve emzirme danışmanlığı yapan hemşirelere katkı sağlayacağını düşünmekteyiz. Yapılacak çalışmalarda bu çocukların uzun dönem sonuçlarının literatüre kazandırılmasını öneriyoruz.

Etik Komite Onayı: Bu çalışma için etik kurul iznine gerek yoktur. Bebeğin annesinden sözlü ve yazılı onam alınmıştır.

Çıkar Çatışması: Yazarlar çıkar çatışması bildirmemişlerdir.

Yazar Katkıları: Fikir-NÇ, ÖT; Denetleme-NÇ, İC; Malzemeler- İC, ÖT; Veri toplanması ve/veya işlemesi- ÖT, İC; Analiz ve/veya yorum-NÇ, İC, ÖT; Yazıyı yazan- NÇ, İC, ÖT

Hakem değerlendirmesi: Dış ba ğımsız.

\section{KAYNAKLAR}

1. Haninger-Vacariu N, Herkner H, Lorenz M. et al. Exclusion of pregnancy in dialysis patients: diagnostic performance of human chorionic gonadotropin. BMC Nephrology. 2020; 21 (70):1-10.

2. Vázquez-Rodríguez JG. Hemodialysis and pregnancy: technical aspects. Cir Ciruj. 2010;78 (1):93-96.

3. Abu-Zaid A, Nazer A, AlOmar O, Al-Badawi
IA. Successful Pregnancy in a 31-Year-Old Peritoneal Dialysis Patient with Bilateral Nephrectomy. Case Reports in Obstetrics and Gynecology. 2013;173405:1-5.

4. Hladunewich MA, Hou S, Odutayo A. et al. Intensive Hemodialysis Associates with Improved Pregnancy Outcomes: A Canadian and United States Cohort Comparison. J Am Soc Nephrol. 2014; 25:1103-1109.

5. Chou CY, Ting IW, Lin TH, Lee CN. Pregnancy in Patients on Chronic Dialysis: A Single Center Experience and Combined Analysis of Reported Results. European Journal of Obstetrics \& Gynecology and Reproductive Biology. 2008;136:165-170.

6. Sulaiman K, Vuppali M, Abreo K. Patient Outcome in Pregnancy Requiring Dialysis: A Case Series. The Open Urology \& Nephrology Journal. 2014;7:52-55. doi: 10.2174/1874303X01407010052

7. Jesudason S, Grace BS, McDonald SP. Pregnancy Outcomes According to Dialysis Commencing Before or After Conception in Women with ESRD. Clin J Am Soc Nephrol. 2014;9:143-149. doi: 10.2215/CJN.03560413

8. Hladunewich M, Schatell D. Intensive Dialysis and Pregnancy. Hemodial Int. 2016;20(3): 33948. doi: 10.1111/hdi.12420

9. Kaplan YC, Uysal N, Arslan EK, Acar S, Harvey C. Emzirme döneminde ilaç kullanımı. Türk Aile Hek Derg. 2019;23(4):176-185. doi: 10.15511/tahd.19.00476

10. Balzer MS, Gross MM, Lichtinghagen R, Haller H, Schmitt R. Got Milk? Breastfeeding and Milk Analysis of a Mother on Chronic Hemodialysis. PLoS ONE. 2015;10(11): e0143340.

11. Dinelli MIS, Ono E, Viana PO, dos Santos AMN, de Moraes-Pinto MI. Growth of children born to renal transplanted women. Eur J Pediatr. 2017;176(9):1201-1207. doi: 10.1007/ s00431-017-2965-1

12. Sgro MD, Barozzino T, Mirghani HM, et al. Pregnancy Outcome Post Renal Transplantation. Teratology. 2002;65;5-9. 
Tablo 1. Bebeğin Postnatal İzlemleri

\begin{tabular}{|l|c|c|c|}
\hline \multicolumn{1}{|c|}{ Postnatal dönem } & Anne Sütü & Ăğırlık & Persentil \\
\hline $\begin{array}{l}\text { Doğum haftas1 } \\
334 / 7\end{array}$ & İlk 6 saatte & $1370 \mathrm{gr}$ & $3-10 \mathrm{p}$ \\
\hline $\begin{array}{l}\text { Taburculuk haftas1 } \\
364 / 7\end{array}$ & Anneyi emiyor & $1680 \mathrm{gr}$ & $<3 \mathrm{p}$ \\
\hline 38 haftalık & Anneyi emiyor & $2000 \mathrm{gr}$ & $<3 \mathrm{p}$ \\
\hline *Postkonsepsiyonel 2 haftalık & Anneyi emiyor & $2900 \mathrm{gr}$ & $3 \mathrm{p}$ \\
\hline *Postkonsepsiyonel 1,5 aylık & Anneyi emiyor & $3700 \mathrm{gr}$ & $10 \mathrm{p}$ \\
\hline *Postkonsepsiyonel 4,5 aylık & Anneyi emiyor & $6400 \mathrm{gr}$ & $25 \mathrm{p}$ \\
\hline
\end{tabular}

*Düzeltilmiş yaşa göre 